Cambridge Review of International Affairs,

Volume 18, Number 2, July 2005

Routledge

Taylor \& Francis Group

\title{
Strategy, Security, and War in Iraq: The United States and the Gulf in the 21st Century
}

\author{
James A. Russell* \\ Naval Post-Graduate School, USA
}

\begin{abstract}
Over the course of events taking place in and around the Persian Gulf over the last three years, the United States has used force to replace a despotic dictator who once served Western interests, placed considerable distance between itself and its erstwhile regional partner Saudi Arabia, and reduced its role as arbiter in the Arab-Israeli dispute. Operation Iraqi Freedom would seem to reveal that the United States has chosen a broader vision for the role that force could play as part of a more aggressive security strategy. The Gulf littoral's forward-deployed footprint, set into place during the first Gulf War, enabled effects-based capabilities to be tested in Iraq that have come online since the 1990s, enabling the US military to begin to operationalise what was initially dubbed the 'Revolution in Military Affairs' and now is called 'Transformation'. As such, the Gulf infrastructure provides the US with a model to emulate around the world as it seeks to realign its forces to better address new threats in the global theatre. The Gulf facilities will become central hubs in the network of bases stretching throughout Central and South Asia and the Horn of Africa which will perform missions associated with the global war on terror. Operation Iraqi Freedom represents only the beginning of this phenomenon in an emerging new global defense strategy that may see forward-deployed forces around the world used with increased frequency to manage an uncertain security environment.
\end{abstract}

Analysts, scholars, and policy professionals can be forgiven if they seem somewhat confused over the course of events in and around the Middle East and the Persian Gulf over the last three years. During this period, the United States used force to replace a despotic dictator who had once served Western interests, placed considerable distance between itself and its erstwhile regional partner Saudi Arabia, and reduced considerably its role as arbiter in the Arab-Israeli dispute. Each of these three elements had at one time or another served as an important pillar in US regional security strategy during the last twenty years.

The abandonment of the peace process and the new distance between the United States and the Saudis, while interesting, are partially explainable by circumstance and domestic politics. The aftermath of the September 11 attacks placed inordinate pressure on an already frayed US-Saudi political partnership and followed a decade of drift in what was once a strategic relationship. As for

*The views in this article are the author's own and do not reflect the views or positions of the Department of Defense. The author expresses his gratitude to the anonymous reviewers and Editor-in-Chief Roxane Farmanfarmaian for their helpful comments on an earlier version of the manuscript.

ISSN 0955-7571 print/ISSN 1474-449X online/05/020283-19 @ 2005 Centre of International Studies 
the peace process, the Bush administration came into office in 2001 openly stating its belief that the United States had become too involved in trying to broker a deal between Israel and the Palestinians. Making good on its campaign rhetoric, the Bush administration only half-heartedly engaged with the parties and eventually all but abandoned the so-called 'peace process' by refusing to forcefully pressure both parties to implement the Road Map and watched in curiously detached isolation as the parties continued to brutalise one another in a seemingly neverending spiral of violence.

But the decision to use force against Iraq is more difficult to explain and to place within a broader framework that makes sense in the context of US regional strategy and policy. While it is true that a recalcitrant Saddam and his dormant programmes to develop weapons of mass destruction represented a potential threat to the region, it is also true that Saddam served a useful role in preserving the regional status quo-providing the less populated but oil-rich Sunni Gulf states with a bulwark against the Shiite state of Iran. President Reagan initiated a re-examination of the US-Iraqi relationship in the early 1980s due to concern on the National Security Council (NSC) about the prospect of an Iranian victory in the Iran-Iraq War, and Rumsfeld was appointed special envoy to Baghdad, where he met with Saddam in December 1983. This important and often missed nuance of US policy towards Iraq and the Gulf during the 1990s was based on the implicit assumption that the US wanted Saddam weak, but not too weak, which formed the underlying framework to the oft-cited position by various senior officials to 'preserve the territorial integrity of Iraq' - a position that was frequently repeated even after 1997 when the United States publicly endorsed the idea of 'regime change' in Baghdad.

The decision to use force to topple Saddam hence suggests a fundamental departure from assumptions that drove US strategy and policy in the Gulf throughout the post-1945 era. The absence of domestic political pressure to invade Iraq and the outright opposition of many of the United States' alliance partners make the decision to use force that much more interesting. While it is true that the aftermath of the September 11 attacks created a new decision-making environment to address emergent threats, the case that Iraq (in particular its nuclear programme) represented an imminent danger to the United States requiring the use of force was always a weak argument.

\section{A New Cost-Benefit Matrix?}

A rudimentary cost-benefit analysis of the decision to use force against Iraq reveals some interesting calculations. The use of force in Iraq came with considerable domestic political risk to the Bush administration and the wider risks to US international credibility were (and remain) substantial; the financial costs have only begun to be counted; and, last, but not least, the United States is paying with the blood of its servicemen and -women-not to mention the uncounted thousands of Iraqis (Russell 2004a). These are a few of the obvious costs. The principal benefit of using force is that Saddam is gone, with a secondary but more far-reaching benefit being the potential establishment of a new domestic political equilibrium that may be more acceptable to the United States. An incontrovertible result of using force to achieve regime change in Baghdad is that a new 
government eventually will emerge that must inevitably feature a prominent (if not a dominant) role of Sunni and Shia Islamist parties. If the new government in Iraq remotely reflects proportionate representation, Shiite political parties will exercise significant influence over the levers of governmental power in Iraq.

Even this rudimentary cost-benefit analysis reveals another fundamental change in US strategic calculations. Since the 1979 Islamic Revolution in Iran, a critical and underlying objective of United States regional security strategy has been to prevent the emergence and spread of overtly Islamist-style regimes. Today, the United States has apparently reversed course by 180 degrees, intended or otherwise. While it is clear that that the United States did not use force with the specific intent of promoting the spread of Islamist-style governance, this outcome must be considered as an irrefutable result of using force in Iraq.

Over the last 25 years, the United States invested considerable time and effort to bring about a settlement to the Arab-Israeli dispute and in parallel constructed an elaborate security architecture in and around the Persian Gulf that was in part designed to preserve the status quo and prevent the spread of the Islamic Revolution onto the Arabian Peninsula. The two objectives successfully complemented each other during the 1990s. The Gulf security system, which gathered steam with the launching of Operation Earnest Will in March 1987, featured an inherently defensive posture that reflected the strategy of containment adopted after World War II to control the spread of Soviet influence around the world. Containment-and this was true in the Gulf-consisted of a series of isolating concentric rings around the opponent(s). These rings consisted of military and political relationships, forward-deployed forces, and a coordinated diplomatic strategy to maintain international support for the isolation of, in this case, Iran and Iraq.

In the aftermath of Operation Iraqi Freedom (OIF) it seems clear that the United States has abandoned a regional approach that primarily relied on deterrence that, during the 1990s, was backed by the periodic use of force justified by the United States as enforcement actions related to the requirements of United Nations Security Council Resolutions. While the use of force certainly became more commonplace in the no-fly zones in Iraq in the aftermath of Operation Desert Fox in December 1998, the United States still couched the application of force in terms of essentially defensive objectives, such as protecting pilots and continuing to ensure compliance with Security Council resolutions (Weller 2000). In contrast, in OIF, the United States applied force in pursuit of objectives unrelated to a broader defensive strategy of containment and instead used force to fundamentally alter the status quo. One of the outcomes of using force in Iraq may be to provide momentum to the emergence of the kind of Islamist politics that the United States spent the last 25 years trying to contain. How did we come this situation? Understanding the answer to this question can allow analysts and professionals to undertake the task of drawing wider inferences from the situation. Focusing on the wider inferences is the task of this paper.

\section{Back to Basics}

The German strategist Carl von Clausewitz believed that force should always serve as an instrument of policy and not represent an end in itself. Furthermore, 
clear-headed strategic thinking and well-formulated strategic objectives should in turn drive that policy. Clausewitz's maxim is as worth considering today as it was when he formulated it. In today's context in the Persian Gulf, the use of force in Gulf War II should be considered within a broader context of political and military objectives in support of what in modern parlance could be described as a 'strategic vision'. History is replete with examples where victory on the battlefield failed to deliver on the promise of peace and security due to the lack of such a vision (Murray 1986).

The Bush administration articulated a number of objectives for Gulf War II-some of which were complementary and some of which were not: (1) forestall the possibility of reconstituted capabilities associated with Iraq's programme to develop weapons of mass destruction that could threaten the United States and its allies; (2) forestall the possibility that these capabilities could be provided to transnational terrorist organisations targeting the US and its allies; (3) remove a despotic dictator as part of a broader plan to create a regional environment more conducive to stable democracies and open societies. The first two objectives remain politically charged and, while useful for domestic political purposes, somehow seem wanting in terms of Clausewitzian logic. Iraq's nuclear programme was believed to have been largely dismantled during the 1990s. The gaps between Iraq's declarations and the UN's attempts at verification were quite limited in Iraq's missile programme. It is true that significant gaps remained in Iraq's chemical and biological programmes, but using force over disputed amounts of growth media and chemical precursors do not seem to measure up to Clauswitzian logic, particularly since there was no consensus in the intelligence community about the significance of these gaps and whether they constituted a grave and impending threat to the United States.

However, the last objective seems particularly apt in the context of Clausewitz's cited maxim. The idea of using force to effect a wide-reaching transformation of regional politics makes more sense in the calculated end/means tradeoffs that states must make in deciding to go to war. Given that Saddam had shown remarkable outward resilience through 13 years of sanctions and international isolation and that it seemed unlikely he would leave of his own free will, regional political transformation represented a principal and compelling objective that could only be achieved through the use of force. Some suggest that a paper titled 'A Clean Break: A Strategy for Securing the Realm' by Richard Perle and others provided the Bush administration with a blueprint of sorts that articulated an objective of fundamentally altering the internal politics of Arab states throughout the region. ${ }^{1}$ The paper, written in 1996 for incoming Israeli Prime Minister Netanyahu, called, among other things, for regime change in Baghdad as part of a plan to spread democracy around the region and isolate those states resistant to fundamental political change-Saudi Arabia, Syria, Egypt. Spreading democracy, it was argued, would create a new set of actors throughout the region that would be more amenable to reaching a peace treaty with Israel. The paper reflected much of the thinking attributed to Deputy Secretary of Defense Paul Wolfowitz, who is generally credited with penning the first draft of the Bush

\footnotetext{
${ }^{1}$ Text of the paper can be accessed online at < http://www.israeleconomy.org/strat1. htm $>$.
} 
administration's approach to national security strategy in the early 1990s (Lemann 2002).

If the 'Clean Break' paper represented potential blueprint for a new approach in the Middle East, the broader vision for the role that force could play as part of a more aggressive American security strategy was clearly spelled out in a September 2000 report released by the conservative organisation called the Project for New American Century. Many of the senior members of the organisation would assume prominent positions in the Bush administration. The report, titled 'Rebuilding America's Defenses: Strategy, Forces and Resources for a New Century', ${ }^{2}$ called for the United States to assume its mantle of global leadership and take concrete steps to preserve and extend America's position of global predominance. In a passage that could be regarded as the articulation of the Bush administration's new strategic direction-even before the September 11 attacksthe report's authors declared in its introduction that 'The United States is the world's only superpower, combining preeminent military power, global technological leadership, and the world's largest economy. Moreover, America stands at the head of a system of alliances, which includes the world's other leading democratic powers. At present, the United States faces no global rival. America's grand strategy should aim to preserve and extend this advantageous position as far into the future as possible' (ibid., i). The role of the military within this grand strategy, according to the report, was to 'secure and expand the "zones of democratic peace"; to deter the rise of a new great-power competitor; defend key regions of Europe, East Asia and the Middle East; and to preserve American preeminence through the coming transformation of war made possible by new technologies' (ibid., 4).

If using force to expand the so-called 'zones of democracy' as part of a strategy of political transformation represented a central objective of using force against Iraq, it stands to reason that this objective applies throughout the region. The decision to use force in pursuit of Operation Iraqi Freedom as part of a broader strategic vision of political transformation that is linked to battling terrorism seems clear in President Bush's soaring rhetoric linking the toppling of Saddam with a plan to defeat terrorism and spread democracy in the Middle East:

We are rolling back the terrorist threat to civilization, not on the fringes of its influence, but at the heart of its power. In Iraq, we are helping the long suffering people of that country to build a decent and democratic society at the center of the Middle East. Together we are transforming a place of torture chambers and mass graves into a nation of laws and free institutions. This undertaking is difficult and costly-yet worthy of our country, and critical to our security. The Middle East will either become a place of progress and peace, or it will be an exporter of violence and terror that takes more lives in America and in other free nations. The triumph of democracy and tolerance in Iraq, in Afghanistan and beyond would be a grave setback for international terrorism. The terrorists thrive on the support of tyrants and the resentments of oppressed peoples. When tyrants fall, and resentment gives way to hope, men and women in every culture reject the ideologies of terror, and turn to the pursuits of peace. (Bush 2003)

\footnotetext{
${ }^{2}$ The report can be accessed at <http://www.newamericancentury.org/ RebuildingAmericasDefenses.pdf $>$.
} 
This rhetoric, to be sure, only mirrors the verbiage in the Bush administration's National Security Strategy Report, which unequivocally establishes the goal of expanding the zone of democracy around the world as a primary strategic objective. Presumably, expanding the zone of democracy will, in turn, make those states within the zone less prone to support terrorist groups and religious extremists. As noted in the National Strategy for Combating Terrorism, 'Ongoing U.S. efforts to resolve regional disputes, foster economic, social, and political development, market-based economies, good governance, and the rule of law, while not necessarily focused on combating terrorism contribute to the campaign by addressing underlying conditions that terrorists often seek to manipulate for their own advantage' (White House 2003, 23).

The Bush administration's strategy documents make clear that force will be an instrument not just to pre-empt emergent threats but also to expand the zone, forcibly if necessary. In the report's foreword, President Bush emphatically states, 'In the new world we have entered, the only path to peace and security is the path of action' (White House 2002). Using force to effect regime change in Iraq indisputably represented such a path.

If we accept political transformation as a newly articulated strategic objective for the United States in the region, a logical next issue for analysis is whether and/or how such an objective fits within the historical framework of US regional security strategy. Stated differently, does the objective of using force to effect political transformation represent a 'fork in the road' for US security strategy? If so, what role will the use of force play in supporting political transformation in other regional states? And last, what role will forward-deployed forces play in this process and how will the infrastructure established the Gulf serve this broader purpose? The remainder of this paper will examine these questions in an attempt to better define US regional security strategy and to determine if the security framework in the Gulf represents a precursor to an emerging global defence strategy that will unfold in the years ahead.

\section{An Historical Baseline}

To judge whether the United States has established a new and pre-eminent strategic objective in the Middle East requires a brief review of history. United States security strategy in the Gulf and the Middle East remained remarkably consistent throughout most of the post-1945 era. The region was seen as a critical front-line area during the global confrontation with the Soviet Union, and the Azerbaijan crisis of May 1946 is regarded by many as the opening act in the Cold War. Some have argued that the Eisenhower administration's decision to finally embrace the British plan to topple the Mossadegh government in Iran was made not so much in response to the nationalisation of the Anglo-Persian oil company as in the belief that that Iranian communists serving as a front for the Soviet Union could assume a dominant role in Iranian politics (Gasiorowski and Byrne 2004, 225; Palmer 1992, 68-69). To the south of Iran, the gradual integration of Saudi Arabia under the US security umbrella during the 1940s and 1950s flowed from the realisation of the growing strategic importance of Saudi oil to the West as US production declined. In planning documents during the 1950s, the United States examined the possibility of using nuclear weapons as part of an 'oil denial' 
strategy to prevent the Soviet Union from seizing control over Saudi oil fields. Distracted by Vietnam during the 1960s, the US nonetheless still signalled its continuing commitment to Saudi Arabia in July 1963 when it deployed aircraft to the kingdom in response to the Saudi-Egyptian conflict in Yemen (Hart 1998).

Following the British withdrawal east of Suez in 1971, the United States sought to fill the vacuum by building up security relationships with Tehran and Riyadh. The infrastructure within Saudi Arabia was built out during this period, while Iran was sold many advanced weapons. The so-called 'twin-pillar' system unravelled following the 1979 Islamic Revolution in Tehran, and the United States became drawn into an increasingly active and direct role during the Iran-Iraq War in the 1980s. Saddam's Iraq became a part of the new system during the 1980s as the United States reluctantly agreed with the assessment of the Gulf States that Iranian victory on the battlefield would be disastrous for regional security and stability. As a result, the Reagan administration gradually re-established a political relationship with Iraq during the 1980s, removing that country from the list of state sponsors of terrorism in 1982 and re-establishing diplomatic relations with Iraq in November 1984. Both steps paved the way for support to Iraq during the war in the form of intelligence and other non-lethal defence equipment. The actions by the United States represented a de facto acceptance of the view that a strong Iraq served as a useful counter to the political and military threat from Tehran (Borer 2003).

Following the Iraqi invasion of Kuwait in August 1990, the United States spearheaded the coalition to restore order and finally moved completely into the vacuum created by Britain's withdrawal some twenty years earlier. After the war, the United States and the Gulf States reached a series of tacit understandings as part of the expansion of the security umbrella in the 1990s: the Gulf states provided access to facilities and publicly (if unenthusiastically) supported containment; in exchange, the United States guaranteed their security and adopted a policy of non-interference in their internal affairs (Indyk 2002; Russell 2003a). In some ways, this represented a return to the 19th-century arrangements made between the British and the Trucial sheikdoms practised up until the British departure in 1971.

During the 1990s - the period of containment - the logistical infrastructure for the forward-deployed presence took shape as part of a strategy to preserve stability, deter Iran and Iraq, and, if necessary, use force on a short-notice basis to defend US regional interests. Consistent with this approach, the United States negotiated a series of defence cooperation agreements with the Gulf States that (1) reached agreement in principle to pre-position military equipment; (2) granted access to host-nation military facilities; (3) established a framework for militaryto-military interaction; and (4) ensured that US military personnel deployed in these countries would be protected under US law. The United States prepositioned three heavy brigade sets of equipment in the region as part of the plan to build forces quickly in the event of a crisis: one in Kuwait, one in Qatar, and one afloat. These forces were complemented by a continuously present carrier battle group and assets in theatre to enforce the no-fly zones and the trade embargo against Iraq.

In 1995, the Department of Defense identified a number of critical strategic interests in the Middle East-assured access to Gulf oil, protecting freedom of navigation along the sea lines of control, a durable Arab-Israeli peace, 
and security of key regional partners as priorities for the United States (Office of International Security Affairs 1995, 5-10). The system for preserving security established during the 1990s supported these objectives, essentially representing a defensive strategy designed to preserve the status quo. While the United States sought to undermine Saddam's regime through covert means and from 1997 onward adopted a policy of rhetorically embracing regime change, the Clinton administration shied away from the idea of invading Iraq to achieve regime change in Baghdad.

\section{Isn't it Still About Oil?}

Most discussion of US strategy and its vital interests in the Gulf invariably leads to one overriding issue: oil. Despite the curious lack of emphasis of this issue in recent US strategy documents and official government pronouncements, there is no way to get around an inescapable fact: the long-term health of the world's economy depends on the Gulf's ability to continue delivering a predictable, steadily increasing supply of oil to the international community at reasonable prices. In 2003, the Gulf states produced about 22.9 million barrels of oil per day, accounting for $27 \%$ of the world's total. Approximately 15-15.5 million barrels of oil per day transits out of the Gulf through the 34-mile-wide Strait of Hormuz, making the waterway an important pressure point in the world's economy. ${ }^{3}$ The region contains an estimated 715 billion barrels in proven oil reserves, representing $57 \%$ of the world's totals and most of the world's excess production capacity. Nearly $40 \%$ of the world's natural gas reserves also reside in the region. The world promises to become even more dependent on Gulf state oil producers over the next 25 years. By 2025, the Energy Information Administration estimates that the Persian Gulf producers will be exporting 36.4 million barrels of oil per day, more than doubling their current exports of nearly 17 million barrels per day (Energy Information Administration 2004). Developing economies of Asia will become particularly dependent on Gulf oil to sustain their economic expansion over the next two decades.

While various commentators argue forcefully that 'it's still about the oil' in discussing US interests in the Gulf, ${ }^{4}$ the salience of the issue of consumption access seems greatly reduced in the Bush administration's primary strategy documents, and today seems replaced by the need to control international oil pricing. Oil access issues played little if any role in the decision to use force against

\footnotetext{
${ }^{3}$ Figures drawn from 'Persian Gulf Oil and Gas Exports Fact Sheet', Energy Information Administration, Department of Energy, Washington, September 2004, $<$ http://www.eia.doe.gov/emeu/cabs/pgulf.html > .

${ }^{4}$ See Kenneth Pollack's discussion of this issue, as one example (2003). An even more forceful case arguing for the transcendent importance of oil in US strategy in the Persian Gulf is made by Andrew Bacevich (2005). Bacevich argues that the so-called war on terror and the pursuit of democracy are subsumed by the overriding strategic requirement that the American way of life requires unlimited and unfettered access to imported oil. He states that from 1980 to the present, 'Regardless of who happened to be occupying the Oval Office, universal values did not figure prominently in the formulation and articulation of U.S. policy in the Persian Gulf. Geopolitics routinely trumped values in the war. Everyone knew that the dominant issue was oil, with Saudi Arabia understood to be the crown jewel' (pp. 58-59). Another variant on this argument can be found in Telhami (2002). Telhami places the US approach in the Gulf within a strategy of denying access to Gulf oil to hostile powers.
} 
Iraq, which was not the case in $1990-91 .^{5}$ While US troops moved quickly to secure Iraq's oil fields and protect Baghdad's Oil Ministry from looters at the outset of OIF, control over Iraq's 110 billion barrel oil reserves seemed to play little role in the Bush administration's war objectives. In the context of regional strategy, the objective of generally preserving the free flow of oil to international markets receives scant attention in the National Security Strategy, while greater emphasis is placed on preserving more stable sources of oil access (the best being neighbourly Canada and Mexico), and expanding domestic energy resources: 'We will strengthen our own energy security and the shared prosperity of the global economy by working with our allies, trading partners, and energy producers to expand the sources and types of global energy supplied, especially in the Western Hemisphere, Africa, Central Asia and the Caspian region' (White House 2004, 19-20). Vice President Cheney's report on national energy policy also places little particular emphasis on the Gulf (White House 2001). With the world's major oilproducing region barely mentioned in this context, it is hard to escape the conclusion that the Bush administration seems to have recast as a strategic priority US access to Gulf oil. Instead of emphasising control over the region's resources as a geopolitical tool, the Bush administration instead emphasises the Gulf's importance for price stability in world oil markets.

\section{Going on the Offence: Operation Iraqi Freedom and the Gulf Reconsidered}

While the merits of the various justifications for using force in OIF can be debated, there can be no doubt that the decision-making environment surrounding the decision to topple Saddam took place against the backdrop of the September 11 attacks (Wirtz and Russell 2003). After the attacks, the Bush administration promulgated a series of strategy documents stating that the United States would use force in a widening number of circumstances. Confronted by a seemingly new and more dangerous security environment, the Bush administration summarily rejected the idea of waiting to be attacked by an adversary as the pre-eminent circumstance under which the country would respond with force. Instead, the Bush administration promised to act as threats emerged and to eliminate them using force before the threats matured. As noted in the National Security Strategy report, 'The United States has long maintained the option of preemptive actions to counter a sufficient threat to our national security. The greater the threat, the greater is the risk of inaction-and the more compelling the case for taking anticipatory action to defend ourselves, even if uncertainty remains as to the time and place of the enemy's attack. To forestall or prevent such hostile acts by our adversaries, the United States will, if necessary, act preemptively' (White House 2002, 15).

At the same time the Bush administration articulated the idea of using force to pre-empt emerging threats and attack hostile terrorist groups on a global basis, a parallel development was gathering steam in American military institutions. Initially dubbed the 'Revolution in Military Affairs' and now called 'Transformation', new concepts of conducting warfare were taking shape as the nation's military institutions started to integrate technological advances in data processing

\footnotetext{
${ }^{5}$ See Woodward (2004). As revealed in Woodward's highly credible reporting on the Bush administration's internal deliberations leading up to the Iraq war, access to Gulf oil seemed to have little if any role in the decision to use force.
} 
and delivery that swept through society in the 1990s. An important subset of military transformation is called 'network-centric warfare', in which US forces are increasingly tied together in encrypted command and control networks, greatly increasing situational awareness, combat capability, and efficiency. In short, network-centric operations offer more destructive power, more quickly, and with less manpower. During the second half of the 1990s, the strategic backbone for network-centric operations took shape. The military integrated the Global Command and Control System (GCCS) into the force structure, which provided the ability to link data feeds from a variety of different sensors into a fused common operational picture. The enhanced situational awareness available to US forces at the strategic and operational levels is in the process of being made accessible at the small unit level. The Defense Department is in the process of developing a system to feed this situational awareness down to a unit-level intranet with something called the Global Information Grid (GIG) (Weiner 2004).

At the end of the 1990s in concert with the integration of GCCS was the fielding of a new generation of precision-guided standoff munitions that enabled the physical destruction of targets with minimal risks to delivery platforms and US troops. Enhanced situational awareness, networked forces, and standoff strikes against differentiated target sets were dubbed by the press 'shock and awe' during OIF. The military refers to the operational concept as 'effects-based operations'. The Joint Forces Command defines the concept as 'A process for obtaining a desired strategic outcome or "effect" on the enemy, through the synergistic, multiplicative, and cumulative application of the full range of military and nonmilitary capabilities at the tactical, operational, and strategic levels'. ${ }^{6}$ Applying force using the principles of effects-based operations entailed an entirely new scheme of targeting a potential enemy. Instead of an attrition, campaign-style of military operations with large numbers of forces built up over time, effects-based operations offered the promise of destroying an enemy's will to fight through the synergistic effects of coordinated targeting, information operations, and special forces.

Some believe the air campaign in Gulf War I represented the first use of effectsbased operations (Warden 1995). Most analysts agree OIF was deliberately planned and executed using concepts associated with effects-based operations. The infrastructure and forward base of operations established in the Gulf during the 1990s proved to be instrumental in executing the stunning conventional phase of OIF-albeit against an incompetent foe. Coordination of the build-up in the Gulf would have been much more difficult without the forward command elements in place in Kuwait, Bahrain, and Qatar. Execution of invasion itself was commanded largely out of the facilities in Qatar (Camp As Sayliya and Al Udeid), which also coordinated air operations using ground- and sea-based strike aircraft. Though it was largely hidden from public view, the Saudis as usual provided access to their airspace and their facilities for a variety of US forces involved in OIF.

The forward-deployed footprint proved instrumental in using force against Iraq, and represents a powerful and continuous reminder to other regional states of US conventional military strength. Consistent with the objectives of the Quadrennial Defense Review and the National Military Strategy, these forces thus

\footnotetext{
${ }^{6}$ Joint Forces Command Glossary, < http:/ / www.jfcom.mil/about/glossary.htm>.
} 
serve the dual purposes of assuring friendly states of the US security commitment (Qatar, Bahrain, Kuwait, the United Arab Emirates, and Israel, for example) while deterring overtly aggressive behaviour on the part of less friendly regional actors such as Syria and Iran. In some respects the forward-deployed footprint also serves as a powerful tool for compulsion that is designed not just to deter aggressions but also to change the behaviour of regional states. The sword of compulsion cuts both ways, it should be noted.

There can be little doubt that the presence of 170,000 military personnel and their equipment in the Gulf is intended to send a threatening message as part of a broader coercive bargaining framework to countries like Iran and Syria, while sending what have to be regarded as more benign but also somewhat ambiguous messages to Kuwait, Bahrain, Qatar, the United Arab Emirates, and Saudi Arabia. Today's military infrastructure in the Gulf serves dual and somewhat contradictory purposes - to reinforce the Bush Administration's framework that seeks to encourage the spread of rules-based governance and global interaction while at the same time helping to preserve the status quo of the existing anachronistic regimes.

It can be no accident that the Gulf states that have welcomed the US military presence with open arms-Kuwait, Qatar, Bahrain, and the United Arab Emirates-are in some respects leading the way in the region towards limited democracy and transparency. While it is unrealistic to expect these states to embrace Western-style secular political systems, these states are embracing other aspects of global rules-based governance that connote a certain 'stability' to the international community. All these states seem determined to position themselves as important operational hubs not just for the US military but as networked centres for the globalised world, moving content, people, and money through their geographic and virtual spaces. Dubai, for example, has positioned itself as a primary resort, financial centre, and trade facility in the global economy. Provided with US security guarantees, all the smaller Gulf states seem to be developing rules-based societies more in accord with the globalising world than the rest of their Middle Eastern cousins (Russell 2004b). Saudi Arabia constitutes the primary and most important exception to this phenomenon, though there seems to be little doubt that Crown Prince Abdullah seeks to move the Kingdom towards political, economic, and social reform (Russell 2003b).

While US military forces and host-nation military facilities may provide a welcome umbrella to the Gulf states that can indirectly encourage the kind of political transformation the United States more actively seeks in Iraq, they also provide a powerful coercive influence over Syria and Iran—states that, according to the Bush administration, constitute a primary threat to security and stability in the international system. The presence of US forces, supported by a newly reconfigured strategic deterrent, provides a seamless web of military capabilities that can be brought to bear in a deterrent, compellant, and direct role on both actors. The redundancy, geographic dispersion, and denial and deception prowess shown by Iran in its nuclear programme shows, if nothing else, an appreciation for US and Israeli military capabilities. The skills shown by the Iranians in hardening and hiding their nuclear footprint also makes a conventional and/or nuclear counterforce scheme of operations that much more difficult for targeteers at Al Udeid, Omaha, and Tel Aviv. 


\section{The Arc of Crisis-Global Strike and the Gulf as Epicentre}

While the Gulf infrastructure is also intended to encourage political transformation and deal with military contingencies within the theatre, it is also clear that these facilities are intended to provide power projection capabilities into distant areas. The role of the Gulf infrastructure in using force in Iraq may be a harbinger of things to come, assuming that using force OIF in pursuit of political transformation was not an anomaly. It seems clear that the basic outlines of the US military footprint in the Gulf may be replicated elsewhere around the world. Various strategy documents highlight the growing importance of forwarddeployed forces to US global security strategy. The Quadrennial Defense Review states, 'Over time, U.S. forces will be tailored increasingly to maintain favorable regional balances in concert with U.S. allies and friends with the aim of swiftly defeating attacks with only modest reinforcements, and were necessary, assured access for follow-on forces' (The Pentagon 2001, 20). A further goal for US forces is to 'increase the capability of its forward forces, thereby improving their deterrent effect and possibly allowing for reallocation for forces now dedicated to reinforcement to other missions'(ibid.). The National Military Strategy further reinforces this point, noting that 'Our primary line of defense remains well forward. Forces operating in key regions are essential to the defense of the United States and to the protection of allies and US interests' (Joint Chiefs of Staff 2004, 9).

The Gulf infrastructure provides the US with a model to emulate around the world as it seeks to realign its forces around the globe to better address new threats. As Under Secretary of Defense for Policy Doug Feith, has noted, 'Key premises underlying our forward posture have changed fundamentally: we no longer expect our forces to fight in place, rather, their purpose is to project power in to theaters that may be distant from their bases. ${ }^{7}$ The Gulf provides the United States the ideal platform upon which to project power not just from the United States but from centre of the so-called 'arc of crisis' that is regarded by Pentagon strategists as the primary problem for US security in the 21st century. Force can be projected both within the immediate environs of the arc but also outside the arc from Gulf bases, complementing the emerging global strike assets that are based in the United States.

The Pentagon is working on a global realignment of forward deployed forces that is intended to address emerging threats from the arc of crisis, which starts in Central and South America and spreads through North Africa, the Middle East, the Persian Gulf, and South Asia. There is discussion of drawing down the presence in Europe and the Korean Peninsula and redeploying these forces to areas in the so-called arc. Noted strategist Tom Barnett has characterised this area of the world as the 'gap'constituting that part of the world that has not developed and/or signed onto the rule sets that characterise interstate interactions in the 'core' countries, which consist of North America, Europe, Russia, and developing Asia. Barnett suggests that the presence of US forces in the Gulf is to 'export security' in parts of the gap still prone to violence and instability. Events in Iraq suggest that the United States will need to 'export security' in this part of the world for the foreseeable future (Barnett 2004). The notion of exporting security is not necessarily a new concept, but is simply another way of linking security and conflict with social and economic

\footnotetext{
${ }^{7}$ Remarks by Douglas J. Feith, Under Secretary of Defense for Policy, 'Transforming the U.S. Global Defense Posture', at the Center for Strategic and International Studies, Washington, 3 December 2003.
} 
development-a linkage that has become particularly pronounced in the post-ColdWar era (Duffield 2001).

A new scheme of supporting forward operations throughout the arc of instability is spelled out in the Bush administration's National Defense Strategy of the United States of America (Department of Defense 2005). Released in March 2005, the report calls for a new global posture that features main operating bases, or MOBs, forward operating sites, or FOSs, and a 'diverse array of more austere cooperative security locations', or CSLs. These facilities are intended to be linked and mutually supportive. Principal operating bases-like the facility at Al Udeid, for example, are well developed with sufficient infrastructure to support large numbers of forces and to receive even larger numbers in times of crisis. Forward operating sites are "scalable, "warm" facilities intended for rotational use by operational forces. They often house prepositioned equipment and a modest permanent support presents. FOSs are able to support a range of military activities on short notice' (Department of Defense 2005, 19-20). The new, networked scheme of forward operating areas can be expected to spread out into the arc of instability from the main operating areas in the Gulf.

Consistent with the requirements spelled out in the Bush administration's strategy documents, a new and diverse array of military facilities are appearing in the Gulf and Central Asia. The developing military footprint inside Iraq will only further complement other facilities in theatre that are already available for use in a variety of contingencies. One commentator has identified as many as six permanent bases in Iraq, with three currently under construction at Baghdad International Airport, Tallil air base near Nasariyah, and Bashur air field in northern Iraq (Johnson 2004). In October 2004, as part of supplemental appropriations to fund ongoing operations in Iraq and Afghanistan, Congress earmarked US\$63 million in military construction funds for improvements at the Al Dhafra airfield in the United Emirates, which accommodated a United States Air Force aerial refuelling detachment during the 1990s. The same bill contained US\$60 million to fund additional enhancements to the Al Udeid airfield in Qatar. In Afghanistan, the United States recently announced plans to spend US\$83 million to upgrade its two main bases at Bagram air base (north of Kabul) and Kandahar airfield to the south. ${ }^{8}$ The funding will be used to expand runways and other improvements to provide new billeting facilities for US military personnel. The expansion of the facilities infrastructure in Afghanistan has been mirrored by the development of facilities and solidified politico-military partnerships in Uzbekistan, Kyrgyzstan, and Kazakhstan (Berman 2004-5). Completing the development of facilities in and around the Gulf, in 2002 the United States established the Combined Joint Task Force Horn of Africa (CJTF-HOA), in Djibouti. The CJTF-HOA is working with regional states to coordinate training and direct action against terrorist groups in the region (West 2005).

\section{The Gulf and the Global War on Terrorism}

The facilities infrastructure throughout the arc of instability, which will be supported through the main operating areas in the Gulf, will feature a different regional footprint and a different kind of force structure from those that populated

\footnotetext{
${ }^{8}$ See Associated Press, ‘U.S. Invests in Upgrades of Afghanistan Bases', 28 March 2005.
} 
the Gulf bases during the era of containment during the 1990s. Those forces conducted continuous operations against Iraq and more indirectly against Iran, exercising pre-positioned military equipment and performing training exercises with host-nation militaries (Office of International Security Affairs 1995). In the future, the structure of forces deployed in the Gulf and to the facilities being established in other parts of the arc will be driven less by requirement to conduct major combat operations than by those associated with the global war on terrorism (GWOT). The footprint of these forces is likely to feature a more prominent role for special forces and strike assets that can be brought to bear on targets with compressed warning time and reduced planning requirements.

A the strategic level, these forward-deployed forces will perform what various Defense Department briefing slides refer to as the 'disrupt' function that will serve to disrupt terrorist networks and complicate terrorist command-and-control cells that are seeking to carry out operations against US forces in theatre and against civilian targets in the continental US. One of the central tenets of the plan to conduct operations against the global Islamist insurgency is to fight forward, conducting military operations throughout the arc of instability. Other missions to be performed by these forces:

- Deny sanctuary to terrorist groups afforded by state sponsors.

- Conduct operations in remote geographic regions that remain outside direct state control, such as the tribal border areas in Pakistan and the Horn of Africa.

- Identify, track, and destroy terrorist groups before those groups can mount attacks on the US homeland. This mission will be accomplished by forwarddeployed surveillance assets, allowing quick targeting and destruction of identified targets-preferably at standoff ranges using the new family of precision-guided munitions, and, if necessary, force-on-force engagements using special operations forces or forward-deployed conventional forces.

- Work with coalition partners in forward operating areas to defeat terrorist groups, with particular emphasis on those countries being threatened by insurgents.

- Engage in psychological and information operations that will discredit Islamist ideologies that are at the core of the insurgent ideology.

- Help create conditions in which terrorist groups lose their legitimacy and base of support within the broader population. Forward-based forces will have to be configured to perform civic action, law enforcement, and other so-called 'stability' operations.

- Retain the flexibility to engage in a variety of forms of warfare, ranging from conventional military operations to 'irregular' or counter-insurgency operations.

- Collect intelligence on targets in forward operating areas. ${ }^{9}$

The Gulf facilities will become central hubs in the network of bases stretching throughout Central and South Asia and the Horn of Africa which will perform missions associated with GWOT. These bases will all be networked together in secure command-and-control links to share intelligence and coordinate operations throughout that part of the arc surrounding the Gulf. Operations commanded out

\footnotetext{
${ }^{9}$ These missions are derived from White House (2003); 'Joint Operating Concept for Defeating Terrorist Organizations' (Pre-coordination Draft), United States Special Operations Command, MacDill Air Force Base, Tampa, FL, 14 November 2003; and Joint Chiefs of Staff (2004).
} 
of the Gulf and performed by forward-deployed forces throughout the theatre will serve as a test bed for emerging concepts of conducting operations against geographically dispersed adversaries. The Defense Department's Office of Force Transformation is undertaking an initiative called the Wolf PAC Distributed Operations Experiment which will 'explore command and control (C2) of geographically dispersed, networked, autonomous and semiautonomous assets'. ${ }^{10}$ These operational concepts feature distributed operations in which small numbers of networked forces would be clandestinely inserted into hostile zones supported by unmanned aerial vehicles and other sensors to target hostile terrorist groups and/or disrupt ongoing terrorist operations.

\section{Transformation and Effects-Based Operations: The Mixed Lessons of Iraq and Afghanistan}

While the United States is moving forward to implement new concepts of applying force which will increasingly feature a predominant role for forwarddeployed forces, the lessons from the two ongoing military campaigns in Iraq and Afghanistan provide very different lessons for planners contemplating the use of force in those parts of the arc of instability in and around the Gulf. In Iraq, the United States executed an extremely successful conventional military operation against an incompetent foe, integrating air, ground, and sea-based assets in a coordinated campaign that effectively brought down Saddam Hussein in several days. But it would be wrong to conclude that the campaign represented a 'triumph' for military transformation and effects-based operations. While the innovative targeting scheme executed by sensors and long-range standoff munitions worked largely as advertised during the assault on Baghdad, much of the US military's modern hardware and sophisticated operational concepts have been less effective in Iraq's urban counter-insurgency environment (Baum 2005). Lacking language skills and overall familiarity with Iraqi society and culture, US ground troops face the difficult task of applying their technological superiority and operational prowess against a societally embedded foe-at least in Iraq's Sunni heartland. Without a clear political decision to raise the level of national commitment, it seems clear that the United States cannot militarily 'defeat' the insurgency and must instead rely on indigenously generated Iraqi forces to root out the insurgents. In short, effects-based operations and the capabilities envisioned in military transformation do not by themselves offer the prospect of 'victory'. As is being relearned by a new generation of troops in Iraq, there is no substitute for language skills, cultural awareness, and tactical intelligence in the fight against the insurgents.

In Afghanistan, the 'military' lessons for the United States are different from those in Iraq, but the implications of the experience there are similar. Like Iraq, Afghanistan represented an astounding success in which relatively small numbers of US forces (numbering several hundred special operations forces)

\footnotetext{
${ }^{10}$ See 'Wolf PAC Distributed Operations Experiment', Transformation Trends, Office of Force Transformation, Department of Defense, 7 December 2004, < http://www.oft.osd. mil/library/library_files/trends_375_Transformation_Trends_7_December_2004_Issue. pdf $>$. Also see 'OFT Launches Initiative to Help Cultivate "Distributed Ops" Concept', Inside the Pentagon, 17 February 2005.
} 
brought down a regime in a relatively short amount of time at little direct cost. Since bringing down the Taliban, US special forces in concert with the International Security Force in Afghanistan (ISAF) led by NATO helped establish security that was critical for the successful national elections of October 2004. These special forces along with Provincial Reconstruction Teams (PRTs) working alongside Afghan nationals are providing security and helping execute reconstruction and stabilisation missions throughout the country. While elements of the Taliban and al-Qaeda remain active on the Afghanistan-Pakistan border, the country is not being subjected to the kind of instability and violence regularly plaguing sections of Iraq. Overall, Afghanistan nation-building is moving forward but at a pace slower than anticipated and it is still too soon to classify Afghanistan as a success-or a failure, for that matter. While the presidential elections of 2004 represent a success, the follow-on parliamentary elections have now been delayed until September 2005. It remains to be seen whether the latest schedule for elections can be met. Despite pronouncements of success by various senior US officials, ${ }^{11}$ other reporting paints a more nuanced picture. In its weekly report covering the period from 24 to 30 March 2005, the European Union's Afghanistan Non-Governmental Organisation Safety Office (ANSO) reported uncertain local security conditions in 26 of Afghanistan's 34 provinces. ${ }^{12}$ In the conventional phase of combat operations, force was applied in an imaginative and ad hoc way that demonstrated flexibility and innovation. In Afghanistan, the existence of easily identifiable internal resistance forces played a significant role helping the United States eject the Taliban. These forces have also helped in the post-conflict phase of operations by helping provide local security. Aided by a coherent opposition that is being moulded into a national-level force, US special forces are working diligently to build indigenous capabilities while simultaneously retaining the means to launch direct action teams against al-Qaeda and the Taliban if necessary to supplement the local defence forces.

But it is easy to overdraw the lessons of the Iraq and Afghanistan cases (which are still being assessed) and hence still more difficult to draw out wider implications from these cases for the new security strategy being implemented in the region by the United States. If there is an overriding lesson for planners of these two cases it is this: history, situation, and context matter in planning and executing military operations. In Afghanistan, the United States had at its disposal an extant and indigenous resistance force-the Northern Alliance-the members of which had been involved in the internal Afghan conflict for much of the past 25 years. The Northern Alliance had a relatively coherent command structure and faced a foe with symmetrical military capabilities. In Iraq, an indigenous underground resistance to Saddam existed in the Shiite south which was almost totally opaque to US planners and, as a result, was of no real use in prosecuting the

\footnotetext{
${ }^{11}$ In the press conference announcing the nomination of Zalmay Khalilzad as US ambassador to Iraq, Khalizad stated, 'In partnership with the Afghan people, particularly Presdient Karzai, we have made great strides. Success in Afghanistan will lead to the political, economic, commercial and ultimately the geopolitical transformation of Central Asia and South Asia.' Remarks posted online, < http://www.state.gov/secretary/rm/ 2005/44285.htm >.

${ }^{12}$ The ANSO Security Situation Summary advises non-governmental organisations to exercise 'caution' or 'extreme caution' in these areas, and generally advises against travel outside urban areas throughout most of the country after dark due to concerns about security.
} 
conventional military phase of the invasion. ${ }^{13}$ The lack of knowledge of the Shiite infrastructure, however, simply flowed from a broader ignorance of Iraqi society, which had been devastated by nearly thirty years of Saddam's totalitarian rule. In Iraq, a new generation of military personnel encountered a environment that had not been seen by the United States as a military occupying force since Vietnam. Thus it is not surprising that the United States has struggled to bring its formidable military capabilities to bear in an extremely difficult counterinsurgency environment tailor-made for an opponent with asymmetric capabilities.

\section{Conclusion}

Events over the last three years in the Middle East indicate that the United States is in the midst of redefining its strategic objectives in the region. It is no longer satisfied with the status quo and preserving historical relationships based primarily on access to energy and stability in world oil markets. The US-Saudi partnership is in the process of redefining itself, while the US relationships with the Gulf states have assumed an ascendant role in terms of their contributions to US military objectives. Unlike the problematic use of Saudi military facilities during the 1990s, the no-strings-attached platforms for military operations in Qatar, Bahrain, Kuwait, and the United Arab Emirates will only become more useful to the United States as it seeks to address emerging threats in and around the arc of crisis. The facilities in the Gulf are now being complemented by additional bases being built in Afghanistan, Central Asia, and the Horn of Africa.

Using force to achieve political transformation in the Middle East and elsewhere, however, means accepting the unexpected, and accepting limits to the control that can be exercised over the very transformation that has been embraced. An Islamist Shiite style of government could emerge in Iraq, one that may well 'request' that the United States depart from their country. Embracing the idea of using force to spur political transformation also means accepting the idea that 'stability' per se in not necessarily a pre-eminent strategic objective. Iraq is a primary example, replete with certain historical quirks that make a less than ideal platform for the test bed of political transformation. The historical legacy of a state characterised by coercion, authoritarian, and centralised state control of political and economic activity in combination with pronounced sectarian and ethnic fissures poses profound challenges for the process of political transformation.

While it is true that the $9 / 11$ attacks redefined global security environment for the United States, that redefinition had other important contributing elements that helped shape the decision to use force against Iraq. The United States arrived at the strategic objective of regional political transformation as a result of a confluence of many different factors. Military transformation, effects-based operations, and the presence of the developed infrastructure played an indirect and supporting role in the political decision to use force in

\footnotetext{
${ }^{13}$ The coherence of internal Shia groups came as a complete surprise to the United States-another aspect of the so-called 'intelligence failure' that has focused primarily on Iraqi weapons of mass destruction capabilities. Since the Shia infrastructure was largely unrecognised by the United States, the latter could not take advantage of it in either the conventional phase of operations or the immediate post-conflict environment. See Jabar $(2003,272-73)$.
} 
Iraq. All these factors combined to help build a case that force could be used in pursuit of political objectives without the accompanying political, economic and social costs that have traditionally been associated with using force. Using fewer numbers of an all-volunteer force in a lightning-style campaign that promised few casualties presented an alluring chimera to decision makers-a chimera that has been largely blown apart by the explosion of the insurgency inside Iraq.

But there can be little doubt that the new American way of war characterised by effects-based operations, long-range conventional and nuclear targeting, and enhanced situational awareness will play a role in future decisions to use force as an instrument of strategy and policy. Operation Iraqi Freedom represents only the beginning of this phenomenon in an emerging new global defence strategy that may see forward-deployed forces around the world used with increased frequency to manage an uncertain security environment. It seems clear that the Gulf infrastructure will continue as an enduring feature-maybe even the centrepiece - of the emerging global infrastructure that will see US forces redeployed around the globe to meet the requirements of expanding the zone of democracy and exporting security to stabilise trouble spots around the world.

\section{References}

Bacevich, A. (2005) 'The Real World War IV', Wilson Quarterly, 29(1), pp. 36-61.

Barnett, T. (2004) The Pentagon's New Map (New York, Putnam).

Baum, D. (2005) ‘Battle Lessons: Annals of War', New Yorker, 80(43), p. 42.

Berman, I. (2004-5) 'The New Battleground: Central Asia and the Caucasus', Washington Quarterly, 28(3), pp. 59-69.

Borer, D. (2003) 'Inverse Engagement: Lessons from U.S.-Iraq Relations, 1982-2000', Parameters, 38(2), pp. 51-65.

Bush, G.W. (2003) Address to the Nation, 7 September, < http://www.whitehouse.gov/ news/releases/2003/09/20030907-1.html >.

Department of Defense (2005) The National Defense Strategy of the United States of America (Washington).

Duffield, M. (2001) Global Governance and the New Wars (London, Zed Books).

Energy Information Administration (2004) International Energy Outlook 2004 (Washington, Department of Energy), < http://www.eia.doe.gov/oiaf/ieo/oil.html > .

Gasiorowski, M. and Byrne, M. (Eds) (2004) Mohammed Mossadeq and the 1953 Coup in Iran (Syracuse, NY, Syracuse University Press).

Hart, P. (1998) Saudi Arabia and the United States: Birth of a Security Partnership (Bloomington, Indiana University Press).

Indyk, M. (2002) 'Back to the Bazaar', Foreign Affairs, 81(1), p. 75.

Jabar, F.A. (2003) The Shi'ite Movement in Iraq (London, Saqi Books).

Johnson, C. (2004) 'America's Empire of Bases', < http://www.alternet.org/story/ $17563 />$.

Joint Chiefs of Staff (2004) National Military Strategy of the United States of America 2004: A Strategy for Today; A Vision for Tomorrow (Washington, Department of Defense).

Lemann, N. (2002) 'The Next World Order', New Yorker, 78(6), p. 42.

Murray, W. (1986) Luftwaffe 1933-1945: Strategy for Defeat (Secaucus, NJ, Chartwell Books).

Palmer, B. (1992) Guardians of the Gulf: A History of America's Expanding Role in the Persian Gulf (New York, Free Press), pp. 1933-92.

Pentagon, The (2001) Quadrennial Defense Review Report (Washington).

Pollack, K. (2003) 'Securing the Gulf', Foreign Affairs, July/August, p. 2.

Russell, J. (2003a) 'Removal of Saddam: The End of an Era', Strategic Insights, 3(2).

Russell, J. (2003b) 'Political and Economic Transition on the Arabian Peninsula: Perils and Prospects', Strategic Insights, 2(5). 
Russell, J. (2004a) 'Strategic Implications of the Iraq Insurgency', Middle East Review of International Affairs, 8(4), pp. 48-55.

Russell, J. (2004b) 'Reform and Governance in the Gulf States', paper delivered at symposium Democracy or Plutocracy? Political Reform in the Middle East, Center for Naval Analyses, Alexandria, VA.

Telhami, S. (2002) 'The Persian Gulf: Understanding the American Oil Strategy', The Brookings Review, 20(2), pp. 32-35.

Warden, COL J. (USAF) (1995) 'Air Theory for thr Twenty First Century', in: Barry Schneider and Lawrence Grinter (Eds), Battlefields of the Future: $21^{\text {st }}$ Century Warfare Issues (Alabama, Air University Press).

Weiner, T. (2004) 'Pentagon Envisioning a Costly Internet for War', New York Times, 13 November, p. A1.

Weller, M. (2000) 'The U.S., Iraq and the Use of Force in a Unipolar World', Survival, 41(4), pp. $81-100$.

West, D. (2005) Combating Terrorism in the Horn of Africa and Yemen (Cambridge, MA, Belfer Center for Science and International Affairs, John F. Kennedy School of Government, Harvard University).

White House (2001) National Energy Policy: Report of the National Energy Policy Development Group (Washington), < http://www.whitehouse.gov/energy/National-EnergyPolicy.pdf $>$.

White House (2002) The National Security Strategy of the United States of America (Washington)

White House (2003) National Strategy for Combating Terrorism (Washington).

Office of International Security Affairs (1995) United States Security Strategy for the Middle East (Washington, Department of Defense).

Wirtz, J. and Russell, J. (2003) 'U.S. Policy on Preventive War and Preemption', Nonproliferation Review, 10(1), pp. 113-23.

Woodward, B. (2004) Plan of Attack (New York, Simon \& Schuster). 